\title{
Fish Drying in Chalan Beel Areas
}

\author{
M. A. Samad*, S. M. Galib and F. A. Flowra \\ Department of Fisheries, University of Rajshahi, Rajshahi-6205, Bangladesh.
}

\begin{abstract}
A study on fish drying in Chalan Beel areas was conducted between August 2006 and February 2007. Field survey was carried out in Atrai, Singra, Tarash, and Bhangura Upazilas adjacent to Chalan Beel to assess the fish drying status. Twenty six fish were used for drying including five major fish species for large scale drying and remaining species were mixed with major species, mostly of damaged physically. Majority (89.3\%) dry fish farmers brought raw fishes from local fish markets or landing centers. Washing of raw fish was done by beel water and poor quality salts were used for salting (rate: 50-250 g / kg fish) in most cases. Majority drying were done by spreading raw fishes on bamboo rack without any protection measure from insects or dust. Finally, maximum dried products were carried to Sayadpur (Nilphamary) dry fish wholesale market by the dry fish farmers or other middlemen.
\end{abstract}

Key Words: Chalan Beel,Fish drying, Dry fish farmer, Raw fish, Marketing

\section{Introduction}

Sun drying of fishes is a simple and the oldest known method of fish preservation where fishes are dried under the sun. Drying method is considered as the least expensive method of fish preservation (Balachandran, 2001). Being the largest beel of the country, Chalan Beel produce huge amount of fish every year. A large number of fish is being used in sun drying in Chalan Beel region. Dried fishes do not lack in importance regarding fish utilization since they are consumed by a substantial number of people. They are the predominant food bringing vital protein to people in rural areas of least developed countries (Graikoski, 1973). Drying is traditional method, which has been used for centuries for preserving fish (Cole and Greenwood-Barton, 1965; Waterman, 1976). Traditional drying is often rudimentary and good hygiene is rarely practiced. During the rainy season, when humidity levels are high, sufficient drying cannot be achieved using traditional methods. In such conditions, stored dried fish will re-absorb moisture and become susceptible to bacteria, fungal or insect attack (Azam, 2002). Though few works were done on fish drying different regions of Bangladesh by Nowsad (2002, 2003, and 2005), Reza et al. (2005) and some other authors but study on fish drying of Chalan Beel region is scant. The present study is focused on the fish drying activities by the dry fish farmers of Chalan Beel areas through field investigation.

\footnotetext{
*Corresponding author:
}

\section{Materials and Methods}

\section{Location and description of the Chalan Beel}

The Chalan Beel is an important water resource in the northwest region of Bangladesh and it is the biggest beel of the country. The total area of this beel in monsoon season is about 300-320 square kilometers whereas in winter and summer the area decreases down to about 50-75 square kilometers. Most of the areas of the Chalan Beel has water depth of about 2-2.5 meters. The Chalan Beel covers an area of Atrai Upazila of Nowgaon district, Singra, Gurudaspur, Boraigram Upazilas of Natore district, Chatmohor, Bhangura Upazilas of Pabna district, and Tarash, Ullapara, Raygonj Upazilas of Sirajgonj district.

\section{Study time and spots}

This study was conducted for a period of 6 months (September 2006 to February 2007). To carry out the present study different spots in Chalan Beel areas were selected. Different fish drying spots in Atrai (Nawgaon); Singra, (Natore); Bhangura (Pabna); and Tarash (Sirajganj) Upazilas were visited for the present study.

\section{Study methods}

Frequent field visits and interviews of the dry fish farmers $(n=56)$ were made to collect necessary data on fish drying. 
Fish drying process was observed in the drying spots of the study areas.

\section{Results and Discussion}

People of Chalan Beel areas carry out sun drying for two purposes viz. business and household consumption. Sun drying for business purpose is generally carried out on rack made of bamboo splits and poles, sometimes on fishing net directly on earth whereas sun drying for household consumption is performed in small scale by using bamboo baskets and small earthen pots (locally called sara) by hanging.

Species used in sun drying: Variety of fishes is being used in sun drying in the study areas. A total of twenty six (26) species of fishes were identified used for drying. Among them, seventeen (17) species were recorded from Atrai, eighteen (18) species from Singra, twenty (20) species from Tarash, and twenty three (23) species from Bhangura areas (Table I). Drying of cultured an exotic fish silver carp (Hypophthalmichthys molitrix) was also observed.

Fish species that are used in sun drying can be divided into two main categories (i) major fish species (95\% of total dried fish) and (ii) minor fish species (5\% of total dried fish) (Fig. 01). Major categories include those fish, which are targeted by the dry fish farmers to be dried and minor species include different fish species that remain mixed with major fish species in small quantity.

\section{Table I. Species recorded in the fishes used for sun drying in different upazilas}

\begin{tabular}{|c|c|c|c|c|c|c|c|}
\hline \multirow{2}{*}{$\begin{array}{l}\text { Sl. } \\
\text { No }\end{array}$} & \multirow[t]{2}{*}{ Scientific name } & \multirow[t]{2}{*}{ Bangla name } & \multicolumn{4}{|c|}{ Name of the upazilas } & \multirow[t]{2}{*}{ Availability } \\
\hline & & & $\begin{array}{c}\text { Atrai } \\
\text { (Naogaon) }\end{array}$ & $\begin{array}{c}\text { Singra } \\
\text { (Natore) }\end{array}$ & $\begin{array}{c}\text { Tarash } \\
\text { (Sirajganj) }\end{array}$ & $\begin{array}{c}\text { Bhangura } \\
\text { (Pabna) }\end{array}$ & \\
\hline 01 & Puntius sophore & Punti & $\checkmark$ & $\checkmark$ & $\checkmark$ & $\checkmark$ & Common \\
\hline 02 & Puntius conchonius & Punti & $\checkmark$ & $\checkmark$ & $\checkmark$ & $\checkmark$ & Few \\
\hline 03 & Puntius ticto & Tit-punti & $\checkmark$ & $\checkmark$ & $\checkmark$ & $\checkmark$ & - do - \\
\hline 04 & Chanda nama & Nama chanda & $\checkmark$ & $\checkmark$ & $\checkmark$ & $\checkmark$ & Common \\
\hline 05 & Parambassis ranga & Chanda & $\checkmark$ & $\checkmark$ & $\checkmark$ & $\checkmark$ & - do - \\
\hline 06 & Parambassis lala & Chanda & $\checkmark$ & $\checkmark$ & $\checkmark$ & $\checkmark$ & Few \\
\hline 07 & Colisa fasciata & Colisa & $\checkmark$ & $\checkmark$ & $\checkmark$ & $\checkmark$ & \\
\hline 08 & Colisa lalia & Colisa & $\checkmark$ & $\checkmark$ & $\checkmark$ & $\checkmark$ & - do - \\
\hline 09 & Hypophthalmichthys molitrix & Silver carp & - & $\checkmark$ & - & $\checkmark$ & - do - \\
\hline 10 & Amblypharyngodon mola & Moa, Mola & $\checkmark$ & - & $\checkmark$ & $\checkmark$ & - do - \\
\hline 11 & Esomus danricus & Darkina & $\checkmark$ & $\checkmark$ & $\checkmark$ & $\checkmark$ & - do - \\
\hline 12 & Botia lohachata & Bou, Rani & - & $\checkmark$ & - & - & Rare \\
\hline 13 & Gudusia chapra & Chapila, Khoira & $\checkmark$ & $\checkmark$ & - & $\checkmark$ & - do - \\
\hline 14 & Tetraodon cutcutia & Potka, Tepa & - & $\checkmark$ & $\checkmark$ & $\checkmark$ & - do - \\
\hline 15 & Channa punctata & Taki, Saitan & $\checkmark$ & - & - & $\checkmark$ & Common \\
\hline 16 & Lepidocephalus guntea & Gutum, Gorkun & $\checkmark$ & $\checkmark$ & $\checkmark$ & $\checkmark$ & Few \\
\hline 17 & Acanthocobitis botia & Balichata & $\checkmark$ & $\checkmark$ & - & - & - do - \\
\hline 18 & Xenentodon cancila & Kakila & - & - & $\checkmark$ & $\checkmark$ & - do - \\
\hline 19 & Mystus vittatus & Tengra & - & - & $\checkmark$ & $\checkmark$ & - do - \\
\hline 20 & Heteropneustes fossilis & Sing, Jiol & $\checkmark$ & - & $\checkmark$ & $\checkmark$ & Rare \\
\hline 21 & Badis badis & Napit & $\checkmark$ & - & $\checkmark$ & $\checkmark$ & Very rare \\
\hline 22 & Mastacembelus pancalus & Guchi & - & $\checkmark$ & $\checkmark$ & $\checkmark$ & Few \\
\hline 23 & Macrognathus aculeatus & Tara baim & - & $\checkmark$ & $\checkmark$ & $\checkmark$ & - do - \\
\hline 24 & Glossogobius giuris & Bele, Baila & $\checkmark$ & $\checkmark$ & $\checkmark$ & $\checkmark$ & - do - \\
\hline 25 & Wallago attu & Boal & - & - & - & $\checkmark$ & Common \\
\hline 26 & Pseudeutropius antherinoides & Batashi & - & - & & $\checkmark$ & Few \\
\hline
\end{tabular}

$\checkmark=$ Yes; - = No 


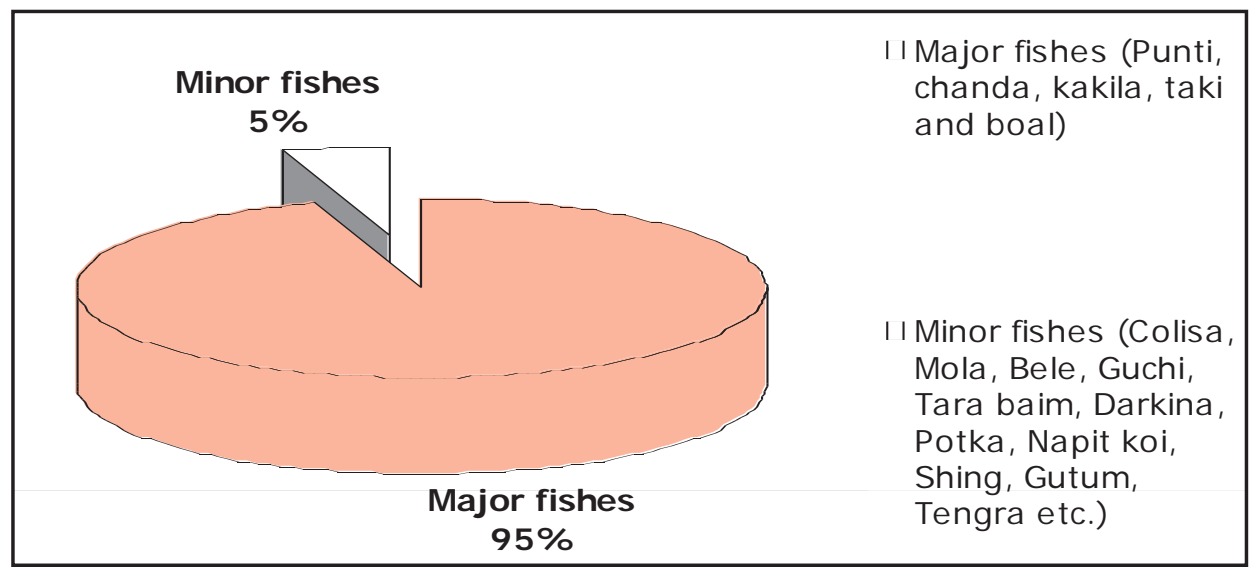

Fig. 1. Fish species used for drying in Chalan Beel regions.

\section{Method of sun drying}

\section{a. Collection of raw fish}

Dry fish farmers collect raw fishes from two sources- local fish markets or landing centers (89.3\%) and from fishermen directly (10.7\%). In most cases, it was observed that low quality damaged fishes were brought from the local fish markets and landing centers for drying. Each dry fish farmer gathered 10-120 kg fresh fish for sun drying everyday depending on availability of raw fish in local markets or landing centers and price of raw fish.

\section{b. Washing}

In most cases, dry fish farmers washed their raw fish with beel water as there was no good water supply sources in drying areas and few dry fish farmers used tubewell water for this purpose. It was also found that, many dry fish farmers did not wash their raw fish.

\section{c. Salting}

It was found that, dry fish farmers in the studied areas used salt for mixing with raw fishes before drying but they did not maintain any fixed ratio of salt and fish. They generally mixed 50-250 g commercial salt for $1 \mathrm{~kg}$ of fishes (Table II).
All the dry fish farmers (100\%) used non-brand commercial salt for salting.

\section{d. Dressing and splitting of raw fish}

Only for large fish like, boal (Wallago attu), silver carp ( $H$. molitrix) and taki (Channa punctata) gutting and splitting were practiced. First the fishes were deheaded and then alimentary canal was removed from the body. In case of taki (C. punctata) only beheading and gutting were done before drying (Plate 01). In case of boal (W. attu) and silver carp ( $H$. molitrix) after beheading and gutting, splitting were done for uniform drying of all parts of muscle. Other small fish species were directly dried under the sun without any dressing.

\section{e. Drying under the sun}

For comparatively large scale fish drying, bamboo made rack of 0.6-1.2 meter high from earth is used in most cases. A bamboo splits made mat is used on the rack over which raw fishes were spread for drying. It was observed that, in some places like Kaliganj (in Singra Upazila) fishes were spread on fishing seine nets directly on earth without using any bamboo rack (Plate 02). Sometimes large fishes like taki (C. punctata) and silver carp (H. molitrix) were hanged from

Table II. Dry fish farmers and amount and type of salt used by them

\begin{tabular}{l|c|c|c|c|c}
\hline Sl. No. & Upazila & District & $\begin{array}{c}\text { No. of Dry } \\
\text {-fish farmer }(\mathrm{n}=56)\end{array}$ & $\begin{array}{c}\text { Amount of salt used } \\
\text { (g /kg raw fish) }\end{array}$ & Type of salt used \\
\hline 1 & Atrai & Naogaon & $16(28.57 \%)$ & $100-200$ & Non-brand commercial \\
2 & Singra & Natore & $23(41.07 \%)$ & $100-150$ & Non-brand commercial \\
3 & Tarash & Sirajganj & $09(16.07 \%)$ & $50-100$ & Non-brand commercial \\
4 & Bhangura & Pabna & $08(14.29 \%)$ & $200-250$ & Non-brand commercial \\
\hline
\end{tabular}


a rope tied horizontally to the two poles placed vertically for drying instead of using any rack.

During drying on the bamboo made racks, dry fish farmers turned over spread fishes at regular interval for better drying. Only $16.07 \%$ dry fish farmers used fishing nets over the rack to prevent fish from insect infestation. Drying duration extremely varied with weather conditions like available sunlight, temperature, relative humidity, wind flow, raining status etc. In the surveyed areas, at normal weather condition (enough sunlight, temperature, humidity, and no rain) drying duration recorded to be varied from 2-6 days depending on the size of the raw fishes.

\section{f. Sorting}

Except for large fishes, other fishes remained in mixed condition and were sorted after drying. Generally 3-6 dry fish farmers sorted out the mixed dried fishes and separated the fish according to the species and size of the dried fish.

\section{g. Packaging}

After sorting, the dried fishes were bagged into a plastic and hessian bag for easy handling (Plate 03). Sometimes bamboo baskets were also used for this purpose.

\section{h. Storage}

Storage of dried fish was found to be performed in a tent generally made of thin plastic sheet and bamboo splits. This

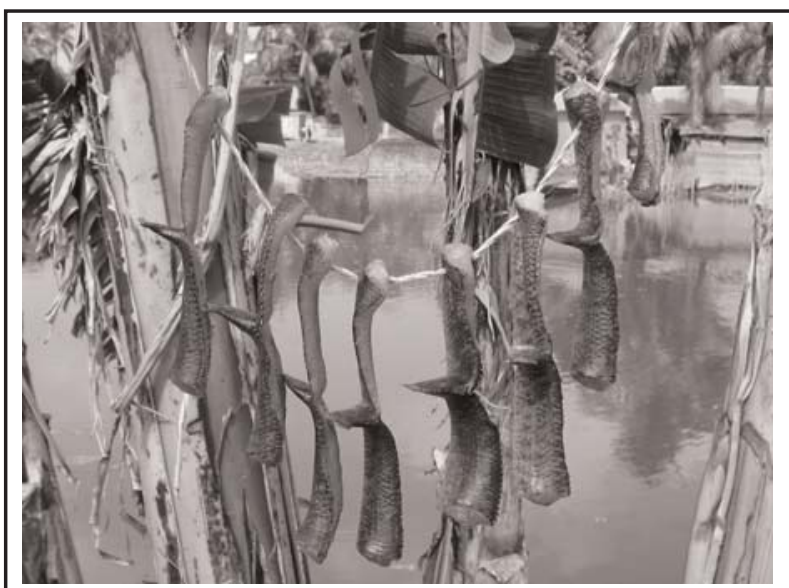

Plate 01: Drying of beheaded taki ( Channa punctata)

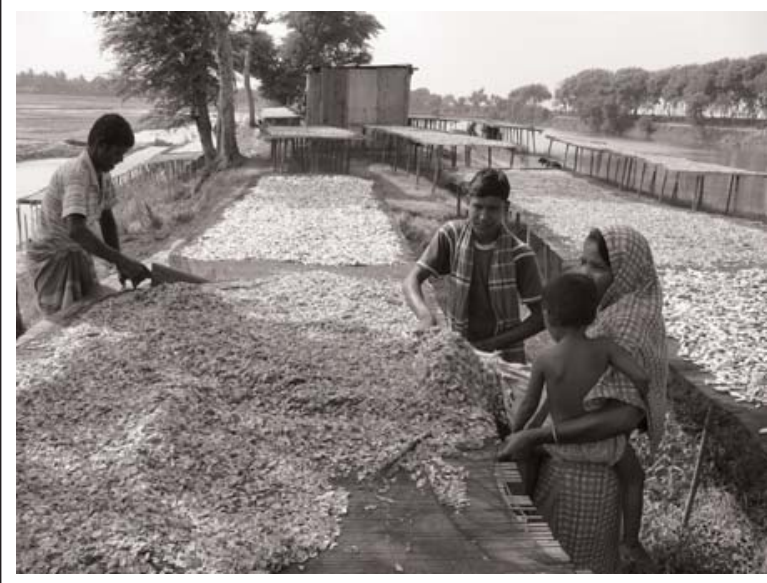

Plate 02: Collection of dried fish in hessain bag.

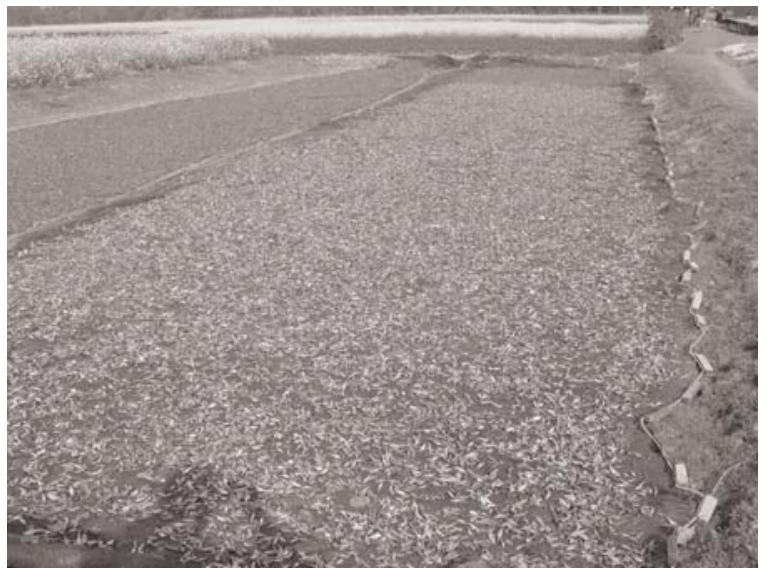

Plate 03: Drying on earth using only net

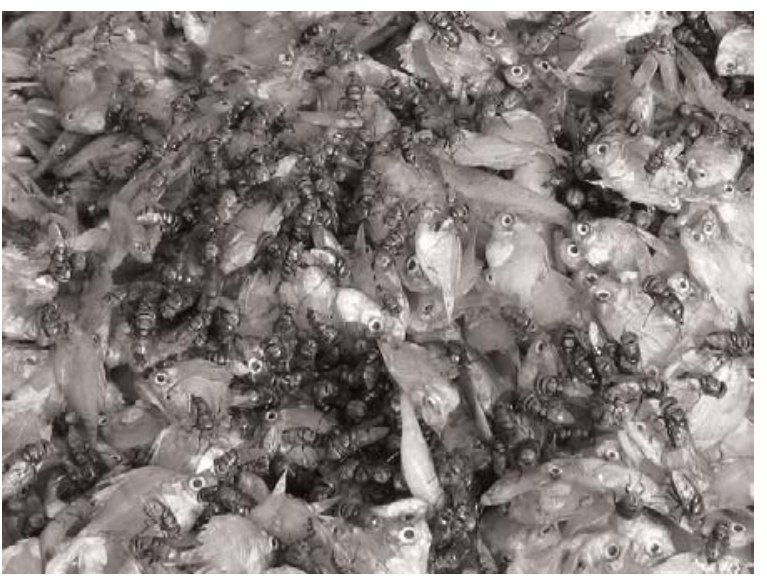

Plate 04: Infestation of raw fish by flies. 
tent is usually made in the place of fish drying. Bagged dried fishes were kept into these tents for temporary storage until marketing or selling to the local vendors.

\section{j. Transportation and Marketing}

In the studied areas, dried fishes were marketed by the dry fish farmers at every 7-15 days interval. There is little information about the quality aspects of fresh fish and the dried products in different stages of marketing chains since no detailed survey was conducted in Bangladesh (Nurullah et al., 2005). It was found that almost all the dried fish product (98-99.5\%), dried in Chalan beel areas, carried to the Sayadpur dry fish wholesale market in Nilphamary district. Very small amount of dried products (0.5-2\%) were consumed locally. Marketing channel of dried fish in the study areas consisted of dry fish farmers, several middleman (local vendor, Bepari, Aratdar, distributor, and retailer), and consumer. However, five (5) types of dried fish marketing channels were observed during the investigation period (Fig. 02).

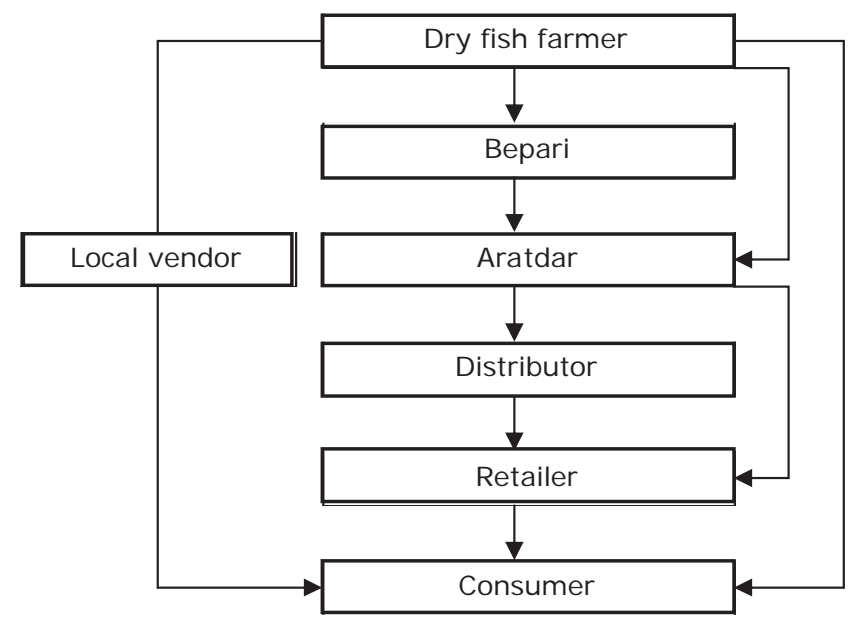

Fig. 2. Marketing channel of dried fish of the Chanal Beel.

In Bangladesh, there is a lack of marketing infrastructure for both wholesale and retail markets. Transportation and storage facilities are poor in most part of the country. The involvement of large number of middlemen and commission agents reduce benefit to the fish producers (Ahmed et al., 1993; Mazid, 1994).

\section{Collection of raw fish}

a. from landing centers/markets: $89.3 \%$

b. own catch: $10.7 \%$

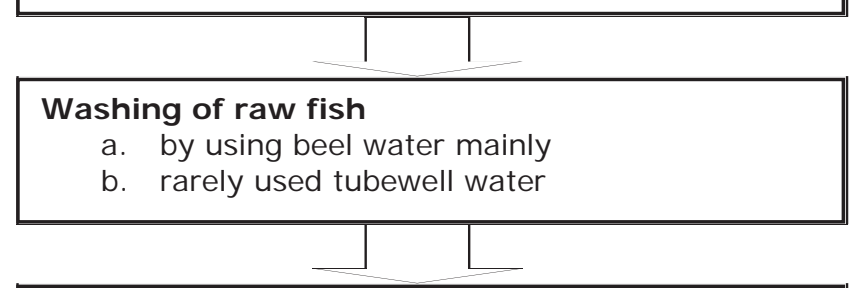

Salting of raw fish

a. use of low quality commercial salt

b. 50-250 g salt / $\mathrm{kg}$ of raw fish

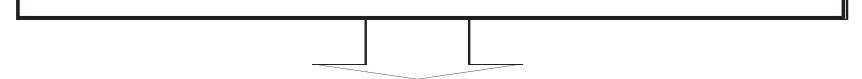

Dressing and splitting of raw fish

a. done for large fishes only

b. small fishes dried without dressing

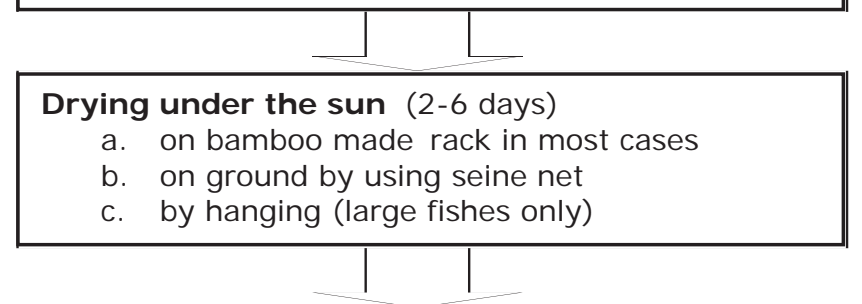

\section{Sorting of dried fish}

(according to species and size of the fish)

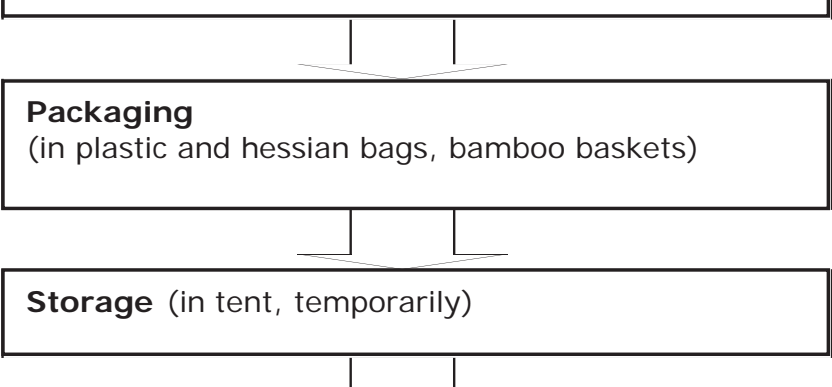

Marketing and selling

(marketed in Sayadpur by train, bus and truck)

Fig. 3. Flowchart of overall fish drying activities in the study areas.

\section{Conclusion}

In most of the observed fish drying places, sun drying is carried out in an unhygienic condition. Due to different reasons, it was observed that poor quality final product was obtained. Different problems observed during study period were selection of poor quality raw fishes for drying, damaged fishes in most cases; washing of raw fishes with dirty water especial- 
ly with beel water instead of tubewell or other water of good quality; use of low quality commercial salt during salting, also proper ratio of salt and fish was not maintained. no dressing of used fishes in many cases; drying directly on earth surface which affect the quality of dried product strongly. moisture, dust and other harmful substances from the environment can easily be mixed to the fish and make the fish susceptible to the microorganism or insect attack, most of the dry fish farmers (83.93\%) did not take any protective measure for protecting the raw fish from insect infestation (Plate 04).

The microbial stability of dried fish products during processing and storage is depended upon their moisture content (Scott, 1957; Waterman, 1976; Chirife and Iglesias, 1978; Troller and Christian, 1978). Sometimes dry fish farmers used insecticides for protecting raw fish from insect attack. This practice greatly affects the quality of final product which is very harmful for human health too. Storage in unhygienic condition was also found which usually took place in the tent having no platform. Sometimes it was also observed that, raw and final dried fishes were kept in the same tent which badly affects the quality of dried final product.

The requirement of a satisfactory dried product is highly desirable and to achieve this, scientific drying method should be practiced in all the drying process. Extension work needs to be done so that there is awareness from dry fish farmers to consumers on handling procedures and quality regulations to ensure reduction in losses and quality of product to market.

\section{References}

Ahmed M., Rab A. and Bimbao M. P. (1993) Household socioeconomics, resource use and fish marketing in two thanas in Bangladesh, ICLARM Tech. Rep. 40: 82p.

Azam K. (2002) Fishermen Community of Kuakata, Bangladesh: Fisheries Activities and Quality of Dried Fish, SUFER Project (DFID-UGC), Khulna University, pp. 2.

Balachandran K. K. (2001) Post-harvest Technology of Fish and Fish Products, Daya Publishing House, Delhi110035, pp. 77.

Chirife J. and Iglesias H. A. (1978) Equation for fitting water sorption isotherms of food, Part-I. A review, J. Food Technol. 13:159-74.
Cole R. C. and Greenwood-Barton L. H. (1965) Problems associated with the development of fisheries in tropical countries. The preservation of catch by simple processes, Trop. Sci. 7: 165-183.

Graikoski J. T. (1973) Microbiology of cured and fermented fish. In: Microbial safety of fishery products (eds. Chichester and Grahm, H.D.), pp. 97-110.

Mazid M. A. (1994) Proceedings of the SAARC workshop on fisheries socio-economics and marketing, BARC, Dhaka.

Nowsad A. A. (2002) Review of solar drying techniques used in the fish drying. GOB/UNDP/FAO Project. BGD/97/017.

Nowsad A. A. (2003) A new method of fish drying in a solar dryer (in Bengali). Food and Agricultural Organization of the United Nations. BGD/97/017.

Nowsad A. A. (2005) Low Cost Processing of Fish in Coastal Bangladesh. Empowerment of Coastal Fishing Communities for Livelihoods Security. GOB/UNDP/FAO Project: BGD/97/017:5/2005, 73p.

Nurullah M., Kamal M., Wahab M. A., Islam M. N., Yasmin L., Shakuntala H., Thilsted and Mazid M. A. (2005) Present status of harvesting, transportation and marketing of freshwater Small Indigenous Species of Fish (SIS) of Bangladesh, Bangladesh J. Fish. Res., 9(2): 159-168.

Reza S. M., Kamal M, Akteruzzaman M. and Islam M. N. (2005) Presentation of drying activities of marine fishes in the coastal region of Bangladesh. Bangladesh $J$. Fish. 27: 46.

Scott W. J. (1957) Water relationships of food spoilage microorganisms, Adv. Food Res., 7: 83-127.

Troller J. A. and Christian J. H. B. (1978) Water activity and food, Academic Press, New York, pp. 216.

Waterman J. J. (1976) The production of dried fish, FAO Fish Tech. Pap., 160: 52.

Received : September 10, 2008;

Accepted : January 18, 2009 